\title{
Chapter 16 \\ Archiving Parliamentary Material
}

We have discussed in Chapter 4 on collection development the need for a parliamentary library to have a comprehensive collection of parliamentary papers and debates as working documents. Parliaments also need to ensure that they have a full archive collection of parliamentary documentation and a policy for retaining and archiving documents for the future. Increasingly archivists will be seeking ways of making this documentation available in digital form. And much modern material will have been created in digital form anyway. This means that access to the archive can be made more widely available but raises further issues of the long term archiving of digital material. There is no need for the parliamentary archive to be part of the parliamentary library, but, as with the public information function, the archive and the library do need to work closely together. The archive will also need to work together with other departments, such as the committee office, to ensure their papers are properly archived. The parliamentary archive may be a separate collection held by parliament itself or it may be part of the national archive of the country.

\section{What the archive might include}

A parliamentary archive can include a wide range of documents relating to the parliament. This will include official papers but may also include other documentation. Examples of materials which might be found in an archive include:

- Original copies of Bills and Acts of Parliament

- Parliamentary debates

- Published committee reports and papers

- Committee papers which have not been published, such as unpub- 
lished evidence to committees and internal working papers of committees

- Minutes of proceedings and other papers relating to proceedings in the chamber of the parliament

- Resolutions passed by the parliament

- Administrative records of the parliamentary administration

- Architectural and historical records relating to the buildings occupied by the parliament

- Shorthand notes of parliamentary proceedings

- Private papers of parliamentarians or of those who have worked in the parliament

- Photographs, sound recordings or other images of the parliament and of individual parliamentarians

This is not an exhaustive list: the archive could reasonably be expected to keep any original documentation relating to the origins, history and activities of the parliament.

\section{Records management policy}

Any parliamentary archive needs to have a records management policy in order to ensure that proper decisions are taken about what records to preserve and what to discard. Essentially the documents to be considered will mainly be ones no longer required as working documents in the parliamentary office which originated them. At first sight it may seem surprising to assume that a parliamentary archive would dispose of any records as there will be many, such as parliamentary papers and records of debates which would never be disposed of. However, as the list above indicates, the archive may contain much more information than this kind of official material. To take a trivial example, it may be desirable to pre- 
serve menus of food served in the parliamentary restaurants. Such information could well be of interest to future historians. But if the menu changes every day and there are several restaurants in the parliament, few would suggest it would be worth preserving all of them. On a more serious level, parliamentary committees may have a wealth of working documents, such as successive drafts of reports, which it would be valuable to have some of, but not necessarily every single one. A records management policy should help decide what is and is not worth preserving in perpetuity and ensure that proper methods are in place for archiving what is to be kept and destroying what is not. Suggested criteria for keeping records in perpetuity are that records accessed by the archives will be retained by the archives on the basis of their evidential, informational and historical value. It is vital that records have attached to them appropriate metadata so that they can be properly accessed when needed. The detailed drawing up of a records management policy will need to be discussed between the archivists in the archive and those working in parliamentary offices.

\section{Digital preservation}

Digital preservation has been attracting more and more attention both because more and more material (probably the vast majority of material originated in parliament) is born digital. And partly because the falling cost of digitising existing material means that it has been possible to make more and more material available in this form and to make it available to be searched by anyone wishing to do so who has access to the internet. This is not the place for a discussion on this complex subject, which has been an issue in the information community for some years. Suffice it to say that if it is not taken seriously there is a risk of data being lost as platforms and hardware change. Paper records decay in time and should ideally be kept in properly controlled conditions, but even if little conscious effort is made to preserve them, they are likely to be still around in hundreds of years. This is even more so for parchment or carvings in stone. However, this is not the case for digital records which will become unusable if active steps are not taken to preserve them as the technology changes. If there are authenticated paper originals this will be a serious problem, but not a disaster as, given time and money, a new 
digital record can be created. For records only existing in digital form their loss would be a disaster. Governments have not always been good at responding to this problem. Parliaments often seem to have a greater awareness of the issues. Preserving digital records requires more conscious effort and collaboration than it does to preserve paper records. Not that the latter is straightforward; there are plenty of issues to do with metadata, proper storage conditions and so on, but left to themselves such records are likely to last for many years. Preservation of digital material is a topic which is regularly raised at IFLA conferences.

\section{Access to archives}

It is part of the role of parliament to ensure that its materials are available to those who wish to access them. Most parliaments have made substantial steps to ensure that debates, committee papers and so on are readily available in electronic and paper form. And parliamentary archives would expect to have a public reading room where the public can consult its holdings. But parliaments have often gone much further than that, as have other holders of historical material such as national archives and national libraries. This has involved projects to make available in digital form much material that was not created digitally. One ambitious project, for example is that for the joint Czech and Slovak Parliamentary Libraries. This project was described in a paper by Eva Maclakova (Head of the Slovak Parliamentary Library) and Karel Sosna (Director of the Parliamentary Library, Czech Republic) to the IFLA conference in Seoul in August 2006 $6^{34}$. This project has included all the records of the Czech and Slovak parliaments and assemblies back to 1848. In 2009 work was continuing on the historical part of the project. A further related project on the Czech (Bohemian) Assemblies Digital Library traces material back to the $11^{\text {th }}$ Century. ${ }^{35}$ Another recent project is that to digitise the United Kingdom House of Commons Official Report back to 1803. Edward Wood presented a paper on the subject at the Ottawa conference on Library and Research Services for Parliaments in August

\footnotetext{
${ }^{34}$ The Joint Czech and Slovak Parliamentary Library. http://archive.ifla.org/IV/ifla72/ papers/087-Malackova_Sosna-en.pdf

$35 \mathrm{http} / / /$ www.psp.cz/cgi-bin/eng/kps/knih/a_snemy.htm
} 
$2008{ }^{36}$ Such projects are potentially extremely valuable and the evidence suggests, for example, that the Czech and Slovak one is well used. However, especially to the non-expert the documentation can often be confusing and it is important to ensure that help is available. For example, the Czech parliament has arrangements whereby enquirers can contact them by email or telephone for advice on how to use the system.

Parliaments often have rich collections of material and their archiving and making them available to the public in both paper and digital form is an important role.

${ }^{36}$ Digitising Hansard: Putting 200 years of Parliamentary Debates Online. http://www. preifla2008.ca/presentation-e.asp?Sub $=$ Yes\&Parent=Pre 
